https://nv.nltu.edu.ua

https://doi.org/10.15421/40280902

Article received 19.09.2018 p.

Article accepted 25.10.2018 p.

$@ \bowtie$ Correspondence author Удк 330.342:303.725.2

Ya. V. Kul'chyts'kyj kulchytskyj.br@ukr.net

Я. В. Кульчицький' Б. В. Кульчицький', С. М. Панчишин ${ }^{2}$

${ }^{I}$ Національний лісотехнічний університет України, м. Львів, Україна

2 Львівський національний університет ім. Івана Франка, м. Львів, Украйна

\title{
ЕКОЛОГІЗАЦІЯ ЕКОНОМІЧНИХ СИСТЕМ ЯК ВИЗНАЧАЛЬНА ДОМІНАНТА ПАРАДИГМАЛЬНИХ ЗМІН В ЕКОНОМІЧНІЙ ТЕОРІЇ ХХІ СТОЛІТТЯ
}

На основі дослідження економічної та екологічної діяльності на початку третього тисячоліття в умовах значного посилення об'єктивних процесів екологізації сучасних економічних систем доведено необхідність переосмислення і перегляду багатьох вже застарілих методологічних положень економічної теорії, іiі поняттєвого апарату. Загострення проблеми взаємин людини і довкілля зумовило утвердження в економічній теорії екологічної парадигми, яка передбачає розгляд усіх економічних і соціальних процесів крізь призму збереження довкілля, умов існування і розвитку людської особистості. Наголошено, що сучасні підручники з економічної теорії недостатньо враховують екологічний імператив, бо необхідно досліджувати поведінку людей у процесі виробництва, розподілу і споживання матеріальних благ та послуг не просто в умовах обмежених ресурсів, а уже в нових умовах - умовах загострення екологічної кризи глобального, регіонального і локального характеру. Розкрито інституційні засади екологізації сучасних економічних систем з позицій постіндустріальної парадигми та економічної компаративістики в умовах посилення глобалізації. Виявлено зміст екологічної парадигми економічної теорії та обгрунтовано необхідність виокремлення соціально-екологічних відносин у системі економічних відносин суспільства. Наголошено на важливості формування сучасної екологічної культури у процесі трансформації економічних систем, коли в iї основі мають бути орієнтованість на екологічну доцільність і безпеку, відсутність протиставлення людини і природи. Запропоновано авторське трактування процесу екологізації сучасних економічних систем в умовах посилення глобалізації, переходу людства до суспільства знань та "зеленої економіки". Під екологізацією економічних систем пропонуємо розуміти посилення екологічної спрямованості економічних систем у процесі їх трансформації, що виявляється у становленні сучасної економічної та екологічної свідомості і культури, екологічної відповідальності, утвердженні сучасних екологічних цінностей, формуванні відповідної нормативно-правової, інституційної бази, спрямованої на суспільний контроль за системою зв'язків "людина - економіка - екологія", застосуванні санкцій і стимулів щодо впливу економічної системи на стан екологічної рівноваги в умовах обмеженості природних ресурсів та загострення екологічної кризи глобального, регіонального і локального характеру. Екологізацію економічних систем є об'єктивним процесом їх трансформації, домінантою трансформації на зламі тисячоліть, що утверджує усвідомлення екологічних проблем як глобальних. Екологізація економічних систем розглядають сьогодні як дуже важливий, навіть визначальний, критерій порівняльного аналізу національних систем чи наднаціональних системних утворень. Запропоноване поняття "екологізація економічних систем", на наше переконання, не тільки заповнить відповідну прогалину в економічній теорії, а й дасть змогу повністю врахувати екологічний контекст дослідження і порівняння економічних систем на порозі третього тисячоліття, відобразить вплив практики на зміну застарілих теоретичних концепцій. Саме екологізація економічних систем і є сьогодні об'єктивною визначальною домінантою парадигмальних змін в економічній теорії XXI ст.

Ключові слова: економічні системи; екологічна парадигма економічної теорії; економічна компаративістика; стійкий розвиток; екологізація економічних систем; парадигмальні зміни в економічній теорії XXI ст.

Вступ. Дослідження економічної та екологічної діяльності, сучасних економічних систем на початку XXI ст. в умовах значного посилення об'єктивних процесів екологізації економічних систем доводить необхідність докорінного переосмислення і дуже часто перегляду, оновлення й зміни багатьох вже застарілих методологічних положень економічної теорії, іiі категорійного,

поняттєвого апарату. Значне загострення проблеми взаємин людини і довкілля зумовило утвердження в економічній теорії екологічної парадигми. Водночас сучасні підручники 3 економічної теорії ще недостатньо враховують вимоги екологічного імперативу. І хоча актуальність проблеми екологізації економіки не підлягає сумніву, проте більшість наукових досліджень і відпо-

\section{Інформація про авторів:}

Кульчицький Ярослав Володимирович, д-р екон. наук, професор, кафедра економічної теорії. Email: kulchytskyj.br@ukr.net Кульчицький Богдан Володимирович, д-р екон. наук, професор, кафедра економічної теорії. Email: kulchytskyj.br@ukr.net Панчишин Степан Михайлович, д-р екон. наук, професор, завідувач кафедри аналітичної економії та міжнародної економіки. Email: kulchytskyj.br@ukr.net

Цитування за ДСтУ: Кульчицький Я. В., Кульчицький Б. В., Панчишин С. М. Екологізація економічних систем як визначальна домінанта парадигмальних змін в економічній теорії XXI століття. Науковий вісник НлтУ України. Серія Економічна. 2018, т. 28, № 9. C. 16-20

Citation APA: Kul'chyts'kyj, Ya. V., Kul'chyts'kyj, B. V., \& Panchyshyn, S. M. (2018). Greening an ecologization of the economic systems as qualificatory dominant of paradigm changes in the economic theory of XXI century. Scientific Bulletin of UNFU, 28(9), 16-20. https://doi.org/10.15421/40280900 
відно навчально-методичних публікацій мають або виключно економічний, своєрідний прагматичний ухил, або природоохоронну спрямованість у чистому вигляді. Звідси випливає необхідність комплексного підходу до цієї складної й надзвичайно важливої наукової і практичної проблеми на основі діалогу економічної теорії XXI ст. та інших наук.

Метою дослідження є обгрунтування необхідності оновлення і навіть зміни застарілих методологічних положень економічної теорії, іiі поняттєвого апарату під впливом утвердження екологічної парадигми, екоцентристської системи цінностей, ідеї так званої "зеленої економіки", відповідної екологічної свідомості та культури. Водночас доводимо необхідність теоретичного виокремлення соціально-екологічних відносин у системі економічних відносин суспільства та відобразити це у поняттєвому апараті економічної теорії. Окрім цього, розкриваємо зміст і вважаємо за доцільне запровадити до наукового обігу в економічній теорії поняття "екологізація економічних систем", оскільки саме цей об'єктивний процес і є сьогодні визначальною домінантою парадигмальних змін в економічній теорії XXI ст.

Методами дослідження є насамперед діалектичний, історичний, логічний, системний, синергетичний, порівняльного, сценарного аналізу, міждисциплінарний та ін.

Ступінь розроблення проблеми та огляд літератури. Варто наголосити, що незважаючи на актуальність проблеми парадигмальних змін в економічній теорії XXI ст. під впливом посилення екологізації економічних систем як пріоритету їх трансформації в умовах епохального переходу людства до інформаційного (постіндустріального за історичною суттю), "знаннєвого" суспільства та "зеленої економіки", у науковців $є$ часто досить різне бачення і тлумачення цієї проблеми. Тому намагатимемось виявити основні підходи до її вирішення та обгрунтувати власну наукову концепцію.

Дослідження економічної та екологічної діяльності на початку третього тисячоліття в умовах значного посилення об'єктивних процесів екологізації сучасних економічних систем зумовлює, на наше глибоке переконання, необхідність переосмислення і перегляду багатьох вже застарілих методологічних положень еконо-

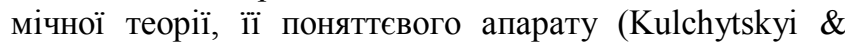
Kulchytskyi, 2015, p. 259; Kulchytskyi, 2017, p. 68; Kulchytskyi, Kulchytskyi \& Malinovska, 2018). Практичними причинами таких тенденцій стали насамперед нагальні проблеми взаємин людини i довкілля (Kulchytskyi \& Kulchytskyi, 2015, p. 259; Kulchytskyi, Kulchytskyi \& Malinovska, 2018). Внаслідок цих складних тенденцій суспільно-економічного буття в економічній теорії почала міцно утверджуватися екологічна парадигма, що передбачає розгляд усіх економічних i соціальних процесів крізь призму збереження довкілля, умов існування і розвитку людської особистості (Kulchytskyi \& Kulchytskyi, 2015, p. 258-259; Kulchytskyi, 2011, p. 240-241; Kulchytskyi, 2003; 2005; 2008; Kulchytskyi, et al., 2017; Kulchytskyi, 2017, p. 6869; Kulchytskyi, Kulchytskyi \& Malinovska, 2018). Як обгрунтовано зазначають у цьому контексті сучасні польські дослідники Б. Фєдор, С. Чая, А. Грачик, 3. Якубчик, екологічна парадигма економічної теорії виростає насамперед 3 критики можливостей традиційного неокласичного оптимізаційного аналізу до вирішення проблеми деградації та охорони довкілля, а та- кож забезпечення відповідної його якості і доступності природних засобів для майбутніх поколінь (Fiedor, et al., 2012, p. 22).

На думку проф. Ю. Туниці, між традиційною ринковою економікою та екологічними вимогами існують глибокі суперечності. Тому головною проблемою сучасної економічної науки повинно стати формування нової екологічної економіки: "Наука повинна зробити все можливе для адаптації ринкової моделі економіки до вимог екологічної економіки, понад це в реальному житті повинна відбутися трансформація ринкової економіки в екологічну" (Tunytsia, 2006, p. 21). Учений слушно вважає, що економічна наука на початку третього тисячоліття мусить змінити або принаймні істотно уточнити свою парадигму, оскільки "предмет класичної і неокласичної економіки стає ширшим i складнішим у зв'язку з розширенням поняття третього фактора виробництва "природні ресурси" до поняття "природне довкілля" (environment)" (Tunytsia, 2006, p. 26-27). Сучасні, найбільш досконалі, зарубіжні підручники 3 економічної теорії (зокрема, авторства К. Макконнела і С. Брю) недостатньо враховують екологічний імператив, бо необхідно досліджувати поведінку людей у процесі виробництва, розподілу і споживання матеріальних благ та послуг не просто в умовах обмежених ресурсів, а уже в нових умовах - умовах загострення екологічної кризи глобального, регіонального і локального характеру. На думку вченого, йдеться про істотні зміни предмету економікс або ж формування поруч 3 класичною і неокласичною економічною теорією нової еколого-економічної теорії чи екологічної економіки, яка $\epsilon, з$ одного боку, продуктом розвитку економічної думки в історичній ретроспективі і спирається на досягнення новітньої економічної теорії, а з іншого, - результатом спостережень та аналізу розвитку сучасного світу, його природи і суспільства, результатом аналізу цілком нових екологічних проблем (Tunytsia, 2006, p. 2629). Загалом Ю. Туниця наголошує: "3 одного боку, екологічна економіка є складовою частиною економічної теорії, з іншого - вона вимагає докорінної зміни сутності й змісту економічних наук щодо відображення ними екологічного імперативу..." (Tunytsia, 2006, p. 83).

Повністю поділяємо точку зору Ю. Туниці, який виводить екологічну економіку з економічної теорії і вважає iї складовою частиною останньої. Справді, яким би не був жвавим діалог економічної та інших наук, але оновлена і збагачена сучасними концептами та постіндустріальною парадигмою економічна теорія є саме тим методологічним фундаментом, річищем, у руслі якого виокремлюється екологічна економіка як віддзеркалення об'єктивного процесу утвердження екологічного імперативу саме в економічній теорії. Підсумовуючи роздуми про екологічний імператив у новітній економічній теорії, учений аргументовано наголошує, що "...повинна відбуватися екологізація економічної теорії та інших економічних дисциплін i, водночас, економізація екології та інших природничих дисциплін" (Tunytsia, 2006, p. 84).

Висновки. Об'єктивні зміни, що відбуваються нині у розвинених економічних системах, повинні, на наше глибоке переконання, знайти відображення у теоретичному виокремленні соціально-екологічних відносин у системі економічних відносин суспільства. При цьому вважаємо, що під соціально-екологічними відносинами 
потрібно розуміти відносини, які об'єктивно складаються між суб'єктами економічної системи суспільства, еколого-економічної діяльності у процесі свідомого перетворення природного світу на основі відповідної економічної та екологічної культури (Kulchytskyi \& Kulchytskyi, 2015, p. 266; Kulchytskyi, 2011, p. 240-318; Kulchytskyi, 2005, p. 105-121; Kulchytskyi, 2003; Kulchytskyi \& Kulchytskyi, 2007, p. 54-58; Kulchytskyi, 2008; Kulchytskyi, Kulchytskyi \& Malinovska, 2018).

Згаданий підхід, справді, дав би змогу не тільки зосередити увагу вчених-теоретиків на розкритті змісту і місця соціально-екологічних відносин у поняттєвому апараті економічної теорії, але й надати потужного поштовху всебічному вивченню особливостей функціонування цих відносин у сучасних розвинених економічних системах для їх максимального врахування в економічній та екологічній політиці країн з перехідними економічними системами у процесі їх трансформації в умовах посилення екологізації та глобалізації (Kulchytskyi, Kulchytskyi \& Dzhyhora, 2016; Kulchytskyi, Kulchytskyi \& Osetskyi, 2017).

Стверджуючи нагальність засвоєння суспільною свідомістю екоцентристської системи цінностей та настанов, ідеї "зеленої економіки", доходимо висновку про глибоке розуміння важливості екологічної свідомості та культури у процесі становлення і трансформації економічних систем, у процесі удосконалення та розвитку методології економічної теорії XXI ст. (Kulchytskyi \& Kulchytskyi, 2015, p. 275-280; Kulchytskyi, 2003, 2005, 2008; Kulchytskyi \& Kulchytskyi, 2007, p. 64-65; Kulchytskyi, Kulchytskyi \& Malinovska, 2018). У підгрунтя формування сучасної екологічної культури мають бути покладені насамперед орієнтованість на екологічну доцільність і безпеку, відсутність протиставлення людини i природи, сприйняття природних об'єктів як повноправних партнерів у взаємодії з людиною (Kulchytskyi \& Kulchytskyi, 2015, p. 278-279; Kulchytskyi, Kulchytskyi \& Malinovska, 2018).

Подальший розвиток економічної теорії у XXI ст. повинен враховувати певну відособленість, автономність наукових досліджень власне екологічних проблем, $з$ одного боку, та досліджень сучасних економічних систем, - 3 іншого, а також діалектичну єдність, нерозривність і глибинну взаємозалежність, взаємозумовленість довкілля, природи, екосистеми та економічної системи. У цьому контексті вважаємо за доцільне запровадити до наукового обігу в економічній теорії XXI ст. поняття "екологізація економічних систем". Під екологізацією економічних систем пропонуємо розуміти посилення екологічної спрямованості економічних систем у процесі їх трансформації, що виявляється у становленні сучасної економічної та екологічної свідомості і культури, екологічної відповідальності, утвердженні сучасних екологічних цінностей, формуванні відповідної нормативно-правової, інституційної бази, спрямованої на суспільний контроль за системою зв'язків "людина - економіка - екологія", застосуванні санкцій і стимулів щодо впливу економічної системи на стан екологічної рівноваги в умовах обмеженості природних ресурсів та загострення екологічної кризи глобального, регіонального і локального характеру. Екологізація економічних систем $є$ об'єктивним процесом їх трансформації, домінантою трансформації на зламі тисячоліть, що утверджує усвідомлення екологічних проблем як глобальних. Екологізацію економічних систем розглядають сьогодні як дуже важливий, навіть визначальний, критерій порівняльного аналізу систем.

Запропоноване поняття "екологізація економічних систем", на наше переконання, не тільки заповнить відповідну прогалину в економічній теорії XXI ст., а переконливо засвідчить і відобразить діалектичну взаємозалежність між науковим, теоретичним осягненням світу, та зворотним, дуже часто випереджувальним, домінантним впливом суспільно-економічної, екологічної практики на докорінне переосмислення й зміну застарілих теоретичних стереотипів, концептів та концепцій. Саме екологізація економічних систем і є сьогодні об'єктивною визначальною домінантою парадигмальних змін в економічній теорії XXI ст.

Запропоноване поняття "екологізація економічних систем" дає змогу максимально, а згодом і повністю врахувати екологічний контекст дослідження і порівняння економічних систем XXI ст. для пошуку та обгрунтування найкращих стратегічних моделей соціуму у третьому тисячолітті. При цьому хочемо наголосити, що "екологізація економічних систем" на практиці - це не просто екологізація економіки шляхом застосування санкцій, штрафів, обмежень і т.ін., а насамперед докорінні зміни на рівні панівних екологічних та економічних суспільних цінностей, інституцій. Тільки такий складний, тривалий у часі, але очевидно, безальтернативний підхід може забезпечити розвиток як національних, так і світової економічних систем, відповісти на виклики цивілізаційного поступу у XXI ст.

\section{Перелік використаних джерел}

Fiedor, B. (Ed.), Czaja, S., Graczyk, A., \& Jakubczyk, Z. (2012). Podstawy ekonomii środowiska i zasobów naturalnych. Warszawa: Wydawnictwo C. H. Beck, 484 p.

Kulchytskyi, Ya. V. (2003). Ekoloho-ekonomichni systemy (problemy teorii i metodolohii doslidzhennia). Lviv: UkrDLTU, 64 p. [In Ukrainian].

Kulchytskyi, Ya. V. (2005). Problemy formuvannia sotsialno-ekolohichnykh suspilnykh vidnosyn u konteksti transformatsii suchasnykh ekoloho-ekonomichnykh system. Lviv: Kamula, 144 p. [In Ukrainian].

Kulchytskyi, Ya. V. (2008). Ekolohizatsiia ekonomichnykh system u konteksti postindustrialnoho paradyhmalnoho dyskursu ta ekonomichnoi komparatyvistyky. Rehionalna ekonomika, 1, 77-84. [In Ukrainian].

Kulchytskyi, Ya. V. (2011). Suchasni ekonomichni systemy v umovakh ekolohizatsii ta hlobalizatsii (teoretyko-metodolohichni zasady porivniannia). Lviv: Liha-Pres, 687 p. [In Ukrainian].

Kulchytskyi, Ya. V. (2017). Formuvannia ekolohichnoi svidomosti ta kultury pid chas vykladannia ekonomichnykh dystsyplin. Ekolohizatsiia osvity yak chynnyk staloho rozvytku suspilstva: Materialy Mizhnarodnoi naukovo-praktychnoi konferentsii, (pp. 68-71). Lviv: RVV NLTU Ukrainy. [In Ukrainian].

Kulchytskyi, Ya. V., \& Kulchytskyi, B. V. (2007). Porivniannia ekonomichnykh system (problemy metodolohii). Lviv: Vyd. tsentr LNU imeni Ivana Franka, 318 p. [In Ukrainian].

Kulchytskyi, Ya. V., \& Kulchytskyi, B. V. (2015). Filosofiia ekonomichnykh system (rozvytok metodolohii yikh porivnialnoho analizu $v$ umovakh ekolohizatsii, intelektualizatsii ta hlobalizatsii). Lviv: Liha-Pres, 710 p. [In Ukrainian].

Kulchytskyi, Ya. V., Kulchytskyi, B. V., \& Dzhyhora, N. V. (2016). Instytutsiini zasady traktuvannia ekonomichnykh system v umovakh posylennia yikh ekolohizatsii ta hlobalizatsii. Scientific Bulletin of UNFU, 26(6), 7-13. [In Ukrainian].

Kulchytskyi, Ya. V., Kulchytskyi, B. V., \& Malinovska, M. V. (2018). An Ecologization of the Economic Systems as Priority of 
Their Transformation in XXI Century. Scientific Bulletin of UNFU, 28(4), 15-19. https://doi.org/10.15421/40280902

Kulchytskyi, Ya. V., Kulchytskyi, B. V., \& Osetskyi, V. L. (2017). Filosofiia ekonomichnykh system u konteksti hnoseolohii suspilnoekonomichnykh transformatsii. (Vol. 6). In H. I. Bashnianyn (Ed.). Ekonomichni systemy, (pp. 60-96). Lviv: Liha-Pres. [In Ukrainian]. Kulchytskyi, Ya. V., Kulchytskyi, B. V., Bashnianyn, H. I., \& Osetskyi, V. L. (2017). Instytutsiinyi pidkhid do traktuvannia eko- nomichnykh system za umov posylennia yikh ekolohizatsii ta hlobalizatsii. In H. I. Bashnianyn, \& B. M. Shevchyk. (Eds.). Systemnyi analiz ekonomichnykh system: Zbirnyk naukovykh prats za materialamy Druhoho Vseukrainskoho kruhloho stolu, (pp. 915). Lviv: Liha-Pres. [In Ukrainian].

Tunytsia, Yu. Yu. (2006). Ekoekonomika i rynok: podolannia superechnostei. Kyiv: Znannia, 314 p. [In Ukrainian].

Я. В. Кульчицкий1 , Б. В. Кульчицкий², С. М. Панчишин ${ }^{l}$ Национальный лесотехнический университет Украины, г. Львов, Украина Львовский национальный университет им. Ивана Франко, г. Львов, Украина

\section{ЭКОЛОГИЗАЦИЯ ЭКОНОМИЧЕСКИХ СИСТЕМ КАК ОПРЕДЕЛЯЮЩАЯ ДОМИНАНТА ПАРАДИГМАЛЬНЫХ ИЗМЕНЕНИЙ В ЭКОНОМИЧЕСКОЙ ТЕОРИИ ХХІ ВЕКА}

На основе исследования экономической и экологической деятельности в начале третьего тысячелетия в условиях значительного усиления объективных процессов экологизации современных экономических систем доказана необходимость переосмысления и пересмотра многих уже устаревших методологических положений экономической теории, ее понятийного аппарата. Обострение проблемы взаимоотношений человека и окружающей среды обусловило утверждение в экономической теории экологической парадигмы, которая предусматривает рассмотрение всех экономических и социальных процессов сквозь призму сохранения окружающей среды, условий существования и развития человеческой личности. Отмечено, что современные учебники из экономической теории недостаточно учитывают экологический императив, потому что необходимо исследовать поведение людей в процессе производства, распределения и потребления материальных благ и услуг не просто в условиях ограниченных ресурсов, а уже в новых условиях - условиях обострения экологического кризиса глобального, регионального и локального характера. Раскрыты институциональные принципы экологизации современных экономических систем с позиций постиндустриальной парадигмы и экономической компаративистики в условиях усиления глобализации. Выявлено содержание экологической парадигмы экономической теории и обоснована необходимость выделения социально-экологических отношений в системе экономических отношений общества. Подчеркнута важность формирования современной экологической культуры в процессе трансформации экономических систем, когда в ее основе должны быть ориентированность на экологическую целесообразность и безопасность, отсутствие противопоставления человека и природы. Предложена авторская трактовка процесса экологизации современных экономических систем в условиях усиления глобализации, перехода человечества к обществу знаний и "зеленой экономики". Под экологизацией экономических систем предлагаем понимать усиление экологической направленности экономических систем в процессе их трансформации, которая оказывается в становлении современного экономического и экологического сознания и культуры, экологической ответственности, утверждении современных экологических ценностей, формировании соответствующей нормативно-правовой, институциональной базы, направленной на общественный контроль за системой связей "человек - экономика - экология", применении санкций и стимулов относительно влияния экономической системы на состояние экологического равновесия в условиях ограниченности природных ресурсов и обострения экологического кризиса глобального, регионального и локального характера. Экологизация экономических систем является объективным процессом их трансформации, доминантой трансформации на изломе тысячелетий, который утверждает осознание экологических проблем как глобальных. Экологизация экономических систем рассматривается сегодня как очень важный, даже определяющий критерий сравнительного анализа национальных систем или наднациональных системных образований. Предложенное понятие "экологизация экономических систем", по нашему убеждению, не только заполнит соответствующий пробел в экономической теории, но и даст возможность полностью учесть экологический контекст исследования и сравнения экономических систем на пороге третьего тысячелетия, отобразит влияние практики на изменение устаревших теоретических концепций. Именно экологизация экономических систем и является сегодня объективной определяющей доминантой парадигмальних изменений в экономической теории XXI ст.

Ключевые слова: экономические системы; экологическая парадигма экономической теории; экономическая компаративистика; устойчивое развитие; экологизация экономических систем; парадигмальные изменения в экономической теории XXI в.

Ya. V. Kul'chyts'kyj1', B. V. Kul'chyts'kyj'2, S. M. Panchyshyn²

${ }^{1}$ Ukrainian National Forestry University, Lviv, Ukraine

${ }^{2}$ Ivan Franko National University of Lviv, Lviv, Ukraine

\section{GREENING AN ECOLOGIZATION OF THE ECONOMIC SYSTEMS AS QUALIFICATORY DOMINANT OF PARADIGM CHANGES IN THE ECONOMIC THEORY OF XXI CENTURY}

On the basis of research of economic and ecological activity at the beginning of the third millennium in the conditions of the considerable strengthening of objective processes of ecologization of modern economic systems, the necessity of reinterpretation and revision of many out-of-date methodological issues of economic theory is well-proven to be its concept vehicle. Intensifying of the problem of mutual relations of man and environment stipulated a statement in the economic theory of ecological paradigm, which foresees consideration of all economic and social processes through the prism of environmental terms of existence and development of human personality preservation. It is marked that modern textbooks on economic theory do not comprise enough an ecological imperative, because it is necessary to investigate human behaviour in the process of production, distribution and consumption of material welfares and services both in the conditions of the limited resources, and already in new terms of intensifying of ecological crisis of global, regional and local character. Institutional principles of ecologization of modern economic systems are exposed from positions of post-industrial paradigm and comparisons of economic systems in the conditions of globalization strengthening. Maintenance of ecological paradigm of economic theory is educed and the necessity of selection of social-and-ecological relations is reasonable for the system of economic relations of society. The importance of forming modern ecological culture is highlighted in the process of transformation of the economic systems, when the basis must be oriented to ecological expediency and safety, and absence of 
contrasting of man and nature. Authors' interpretation of the process of ecologization of modern economic systems is offered in the conditions of globalization strengthening, transition of humanity to society of knowledge and "green economy". We suggest understanding of ecologization of the economic systems as strengthening of ecological orientation of the economic systems in the process of their transformation, which appears in becoming of modern economic and ecological consciousness and culture, ecological responsibility, claim of modern ecological values, forming of corresponding normatively-legal institutional base, sent to the public inspection after the system of connections "man is an economy - ecology", application of approvals and stimuli in relation to influence of the economic system on the state of environmental equilibrium in the conditions of the limited nature of natural resources and intensifying of environmental crisis of global, regional and local character. Ecologization of the economic systems is the objective process of their transformation, by the dominant of transformation on the fracture of millenniums, which asserts realization of environmental problems as global. The ecologization of the economic systems is examined today as very important, even qualificatory criterion of comparative analysis of the national systems or international system educations. We believe the offered concept of "ecologization of the economic systems" not only to fill a corresponding blank in an economic theory but also enable considering the ecological context of research and comparison of the economic systems on the threshold of the third millennium, will represent the influence of practice on the change of obsolete theoretical conceptions. Exactly ecologization of the economic systems is today the objective qualificatory dominant of paradigm changes in the economic theory of 21 century.

Keywords: economic systems; ecological paradigm of economic theory; comparative analysis of the economic systems; sustainable development; ecologization of the economic systems; paradigm changes in the economic theory of 21 century. 